\title{
Josef Alexander Helfert (1820-1910) Předchůdce a vzor Vladimíra a Jaroslava Helfertových
}

\section{Josef Alexander Helfert (1820-1910) Ancestor and Model for Vladimir and Jaroslav Helfert}

\author{
Irena Veselá / irena.vesela@mzk.cz \\ Oddělení dějin hudby MZM; Moravská zemská knihovna, Brno, CZ
}

\begin{abstract}
Josef Alexander Helfert played a significant role in a social and political life of Habsburg Monarchy of the 19th and the beginning of 20th century. He was born in Prague, where he studied law and worked as an active politician in Austrian government from the beginning of 1848 till the sixtieth of 19th century. He worked as a petty secretary for the Ministry of Education and Culture. He markedly contributed to the Austrian educational reform and therefore he was later ennobled and in 1863 became a president of Central Commission for preservation of monuments. He bequeathed a vast literary work, especially from historiography field. His main focus was on history of Austrian state unity from the end of 18th century and throughout the entire 19th century but also on ancient Czech history (e.g. Hus und Hieronymus study). Helfert also dealt with law and education as such, he was an active member in various societies and he was actively engaged in Catholic church. Among his interests were also ethnography, music and history of art. During the periods of growing nationalism and escalating relationships between Czech and German speaking population of the Monarchy, J. A. Helfert remained Czech patriot. But his patriotism was of a provincial character; what mattered to him was not a language but land citizenship. In the same time he stayed loyal and a conservative-thinking citizen of multinational Monarchy ruled by Hapsburg dynasty.

The study concentrates only on the areas of Helfert's interest that were later carried on by his grandsons Jaroslav (1883-1973, director of Moravian Museum in Brno) and Vladimir (18861945, founder of department of musicology at Brno's University and also founder of a music archive based in Moravian Museum). The work briefly introduces his historiographical heritage, his attempts to detect and preserve monuments and assets and furthermore to detect and treat Czech folk poetry in corporation with Otakar Hostinský. It also includes a note on Helf-
\end{abstract}


ert's Prague patriotism expressed in an article about Mozart's tradition in Prague. The author also depicts Helfert's contacts with members of aristocracy and catholic community that his grandsons could later benefit from. Towards the end of the study you can find comparison of Josef Alexander's work with work of his grandsons who, as much as their grandfather, tried to detect and protect material and immaterial historical assets. Their contribution is then dated after 1918, in the atmosphere of newly born Czechoslovak Republic.

\section{Key words}

Joseph Alexander Helfert, Vladimír Helfert, Jaroslav Helfert, Otakar Hostinský, 19th century, Habsburg monarchy, Czech lands, historiography, 1848, Prague, Wolfgang Amadeus Mozart, preservation of monuments

„... Vedle toho chci splatit dluh svému dědovi. Chci vydat z jeho literárni pozůstalosti věci, rád bych sestavil výbor z jeho korespondence, který by osvètlil tuto vzácnou povahu, pracovitou, poctivou, nenáročnou a věrnou. Mnoho jsem mu povinen a ve vězení jsem si uvědomil ono duševni dědictví, které jsem po něm zdèdil."

Vladimír Helfert: Moje literárni plány (11. 1. 1942)1

Těmito slovy si v závěrečném a patrně nejhorším období svého života připomínal Vladimír Helfert odkaz svého děda Josefa Alexandra Helferta. Zakladatel brněnské hudební vědy se v té době nacházel v nemocnici ve Wohlau, kam byl převezen coby vězeň nacistického režimu - vážně nemocen, ale pln velkorysých plánů do budoucna.

Nebylo mu bohužel dopřáno tyto velkolepé plány uskutečnit, ani splatit onen zmíněný dluh, nebot’ zemřel záhy po skončení druhé světové války. Tím však tento dluh nebyl zcela smazán, pouze přešel na další generace historiků. Význam osobnosti Josefa Alexandra Helferta tak do nedávné doby nebyl, alespoň v českém prostředí, řádně doceněn.

Josef Alexander Helfert se do dějin rakouského soustátí zapsal především jako politik působící aktivně v revolučních letech 1848-49 a v době následného desetiletého období neoabsolutismu, dále jako spolutvůrce reformy školství, jako zakladatel dodnes fungujícího Ústavu pro rakouský dějezpyt, prezident Ústřední komise pro zachování památek a v neposlední řadě také jako historik a publicista.

V dílech českých historiků vystupuje Helfert především jako politik spojený s obdobím let 1848-61, a to v souvislosti s aktivitami Palackého, Riegra a dalších. ${ }^{2}$ Své místo

1 HELFERT, Vladimír - SOSNAR, Jura. Hovory tužkou: Listy spoluvězněnému př́teli, Moje literárni plány (1941-1942) (= Knižnice hudebních rozhledů), Praha 1956, s. 73; stat Moje literární plány byla otištěna též v publikaci STRAKOVÁ, Theodora: Vladimír Helfert 24.III.1886-18.V.1945. K výstavẽ „Vladimír Helfert a jeho tvuirči odkaz", vyd. Moravské museum, Brno 1956, citát na s. 9.

2 URBAN, Otto. Česká společnost 1848-1918, Praha 1982; KOŘALKA, Jiří. František Palacký (1798-1876). Životopis, Praha 1998. 
má Josef Alexander Helfert i v dějinách české historiografie. ${ }^{3} \mathrm{~V}$ muzikologických kruzích se o Josefu Alexandru Helfertovi poprvé obšírněji zmínila Eva Drlíková v příspěvku Vladimír Helfert a jeho rod (Od barona $k$ občanovi) předneseném na konferenci Vladimír Helfert v českém a europském kontextu pořádané roku 1986 v Brně Univerzitou J. E. Purkyně ve spolupráci s Moravským muzeem. Drlíková zde upozornila na bohaté intelektuální a společenské zázemí, v němž byla rodina Helfertova po celé 19. století ukotvena, a z něhož Vladimír a Jaroslav Helfertové posléze hojně čerpali ono v citátu zmíněné duševní dědictví. V témže duchu psal o Josefu Alexandru Helfertovi také Rudolf Pečman ve své monografii věnované zakladateli brněnské hudební vědy. ${ }^{4}$

Díky obrovskému množství dochovaného archivního materiálu představuje bádání o osobnosti Josefa Alexandra Helferta velkou výzvu především pro historiky. Pouze zpracování a případná edice korespondence Josefa Alexandra, které měl v plánu Vladimír Helfert, znamenají velký úkol do budoucna, či lépe řečeno zůstávají oním výše zmíněným stále nezaplaceným dluhem. Kromě korespondence se však dochovalo také velké množství dalších Helfertových poznámek a glos, kratších či delších statí vydaných v dobovém denním tisku či samostatně, jeho vytištěné i rukopisné přednášky a studie týkající se témat historických či aktuálně politických (mnohdy jsou tyto dvě oblasti navzájem úzce propojeny) a též nemálo textů zasahujících do problematiky práva, školství, památkové péče atd. $Z$ velké většiny je tento pramenný materiál uložen v Moravském zemském archivu v Brně (fond G 44). Menší a dosud nezpracovaná část pozůstalosti Josefa Alexandra se nachází v archivu Moravské galerie v Brně a další jednotliviny či soubory jsou rozptýleny po dalších českých i rakouských archivech. ${ }^{5}$

Tento př́spěvek si proto nemůže klást za cíl postihnout život a dílo Josefa Alexandra Helferta v celé šiři a podat vyčerpávající informace o všech oblastech, do nichž Helfert během svého dlouhého života zasáhl. Chce poukázat pouze na některé oblasti, v nichž děd Jaroslava a Vladimíra Helfertových inspiroval či mohl inspirovat své vnuky či jim být vzorem a tyto oblasti krátce představit.

Josef Alexander Helfert se narodil 3. listopadu roku 1820 v Praze, v domě stojícím tehdy na rohu Staroměstského náměstí a Železné ulice, ${ }^{6} \mathrm{v}$ rodině právníka a univerzitního profesora Jana Josefa Helferta. Rod Helfertů, usazený od 2. poloviny 18. století v Plánici v západních Čechách, pocházel původně z Německa. Němčina byla také komunikačním jazykem v Helfertově rodině, což ovšem v době metternichovského absolutismu zdaleka neznamenalo sociální izolaci od českého živlu, naopak: k okruhu rodinných přátel

3 NODL, Martin. Národní a zemské zájmy v interpretacích „dekretu kutnohorského“ (Palacký - Tomek - Helfert - Höfler). In AMBROŽOVÁ, Hana - DVOŘÁK, Tomáš - CHOCHOLÁČ, Bronislav - JAN, Libor - PUMPR, Pavel (eds.): Historik na Moravě. Profesoru Jiřimu Maliŕovi, předsedovi Matice moravské a vedoucímu Historického ústavu FF MU, věnuji jeho kolegové, prátelé a žáci k šedesátinám. Brno 2009, s. 83-86; týž: Dějepisectvi mezi vědou a politikou. Úvahy o historiografii 19. a 20. století (= Dějiny a kultura, sv. 14), Brno 2007, s. 15 a 234.

4 DRLÍKOVÁ, Eva. Vladimír Helfert a jeho rod (Od barona k občanovi). In Vladimír Helfert v českém a evropském kontextu. Hudebněvědná konference $k$ 100. výroči narozeni pokrokového vědce a člověka. Brno 1987, s. 102-105; PEČMAN, Rudolf: Vladimir Helfert. Brno 2003, s. 11-13.

5 Srov. ČERNUŠÁK, Tomáš. G 44 - Helfertovi (1812-1910). Inventář MZA v Brně. Brno 2014, s. 7.

$6 \quad$ V témže domě si roku 1848 zř́ídil Bedřich Smetana svou hudební školu. 
patřili také příslušníci česky mluvící pražské inteligence. Josef Alexander vystudoval práva na pražské univerzitě a studium završil ve svých 22 letech doktorátem z obojího práva. Poté vstoupil do státních služeb: ve 40. letech 19. století působil jako praktikant v různých státních institucích v Praze i ve Vídni. Roku 1847 se v Praze oženil s Vilemínou Fügnerovou, sestrou spoluzakladatele sokolské jednoty Jindřicha Fügnera. Společensky měl tehdy blízko k českým obrozeneckým kruhům; byl mimo jiné členem pražské Měštanské besedy, jednoho z politických středisek českých liberálo̊ předbřeznové doby. Téhož roku 1847 přijal místo suplenta na katedře římského a církevního práva na Jagellonské univerzitě v Krakově. V té době již Josef Alexander publikoval svá první díla z oboru práva a státovědy. Zdálo se, že mladý právník půjde ve šlépějích svého otce a že jej čeká univerzitní kariéra právního vědce.

Přišlo však jaro roku 1848 a s ním revoluční události. Josef Alexander Helfert se vrátil z Krakova zpět do Prahy. V červnových volbách do prvního ústavodárného říšského sněmu kandidoval za tachovský okres, kde měla rodina Helfertů své kořeny, a byl zvolen. Opustil tím pádem definitivně místo suplenta v Krakově a tím i započatou pedagogickou dráhu a stal se aktivním politikem. Na půdě ř́šsského sněmu zasedajícího nejprve ve Vídni a poté v Kroměříži se spolu s Františkem Palackým, Františkem Ladislavem Riegrem a dalšími podílel na vypracování návrhu nové rakouské ústavy. Profiloval se jako konzervativní politik středu a jako takového si jej na sněmu vyhlédli tvůrci formujícího se vídeňského vládního kabinetu hrabě Stadion a kníže Schwarzenberg. Po nástupu osmnáctiletého císaře Františka Josefa I. na trůn, který se odehrál v Olomouci na začátku prosince roku 1848, se Helfert, kterému byl ve Schwarzenbergově vládě nabídnut post ministra kultu a vyučování, musel rozhodnout mezi vládní kariérou a přátelstvím s českými liberály. Rozhodl se pro to první: ministerské křeslo sice odmítl, ale přijal místo státního podsekretáře dočasně spravujícího ministerstvo kultu a vyučování. Pro ani ne třicetiletého právníka to znamenalo nebývalý politický vzestup, naopak pro české liberály se situace stala nepříznivou. Původní slibně nastartovaný ústavní vývoj se po nástupu nového císaře zvrátil směrem k neoabsolutismu. Kroměřižský ústavodárný sněm byl v březnu 1849 násilně rozpuštěn a zároveň vydána oktrojovaná ústava. ${ }^{7}$

V Helfertově osobním životě byl rok 1849 rokem štastným a zároveň tragickým: na svět přišel jeho prvorozený a jediný syn Zdeněk, pozdější otec Vladimíra a Jaroslava Helfertových, několik měsíců poté však zemřela Helfertova manželka Vilemína (18271849). Teprve roku 1853 uzavřel Josef Alexander Helfert druhý sňatek s Julií Gredlerovou (1832-1907). Toto manželství zůstalo bezdětné.

Ani v pozici konzervativního vládního úředníka ve Vídni nezanevřel Helfert na české vlastenecké kruhy. Jeho polemiky s o generaci starším zemským historiografem a mluvčím české liberální strany Františkem Palackým, které se týkaly jak aktuálního řešení etnické otázky v habsburské monarchii (Helfertův spis Österreich und die Nationalitäten, ein offenes Wort an Fr. Palacký, vydaný ve Vídni roku 1850) tak výkladu husitství (spis Hus und Hieronymus), se vždy nesly ve zdvořilém tónu. Nutno dodat, že praktická politika a historiografie se ve 40. a 50. letech 19. století prolínaly jako nikdy předtím, což ostatně

7 K Helfertově činnosti v letech 1848-49 nejnověji KUČERA, Rudolf. Konzervativni poučení z revoluce: Politická kariéra J. A. Helferta, in: Moderní dějiny 14 (2006), s. 309-321. 
dokládá i samotná osobnost politicky angažovaného historiografa Františka Palackého. Čeští liberálové naproti tomu ve vztahu k Helfertovi v 50. letech značně ochladli. ${ }^{8}$ Teprve koncem 50. let se státní podsekretář Helfert opět sblížil s Palackým a českými liberály, když se ve vzniklém sporu o Rukopisy královédvorský a zelenohorský jednoznačně postavil na stranu obhájců jejich pravosti. ${ }^{9}$

Helfertovo působení na ministerstvu kultu a vyučování, řízeném od jara roku 1849 Lvem hrabětem Thunem von Hohenstein, se v době neoabsolutismu neslo také ve znamení významných reforem středního a vysokého školství: došlo například ke zrovnoprávnění filozofické fakulty, která byla do té doby pouze fakultou přípravnou. Vládním úředníkem na ministerstvu zůstal Helfert do roku 1861. Po rezignaci svého přímého nadřízeného, hraběte Thuna, a následném zrušení ministerstva kultu a vyučování, zůstal Helfert ve vládě nadále státním podsekretářem pro školství v rámci tzv. státního ministerstva, a to až do své definitivní rezignace roku 1863. Po obnovení ústavnosti v rakouském soustátí jeho politická kariéra fakticky skončila. Zahájil však jinou, pro stát neméně významnou činnost. Téhož roku 1863 byl jmenován prezidentem Ústřední komise pro zachování památek. Byl též nobilitován a roku 1881 jmenován členem panské sněmovny. O návrat do aktivní politiky se pokusil ještě roku 1871, kdy se v konzervativně zaměřeném vládním kabinetu hraběte Hohenwarta ucházel o post ministra školství, avšak bezúspěšně. ${ }^{10}$ Zůstal však aktivně činný v panské sněmovně, a to až do prvního desetiletí 20. století. Zemřel ve Vídni dne 16. března roku 1910 v úctyhodném věku 89 let.

Helfertovým základním životním i politickým postojem byl konzervativismus spojený s katolickou vírou a loajalitou vůči vládnoucí dynastii. Charakteristické pro něj bylo zemské vlastenectví, v němž nehrály zásadní roli etnické a jazykové kořeny, nýbrž příslušnost k dané zemi - v případě Josefa Alexandera nejen k rodným Čechám, ale též k celému rakouskému soustátí. V ovzduší tohoto zemského vlastenectví vyrůstal Josef Alexander Helfert v době předbřeznové a uchoval si tento postoj i po roce 1848 , kdy se české národní obrození již natrvalo politizovalo a vyhranilo vưči taktéž radikálnímu německému nacionalismu. I za této situace Helfert věřil, že společná loajalita všech národností vůči rakouskému soustátí a jeho panovníkovi dokáže sjednotit v jednom státním celku Němce i Slovany. Tuto ideu prosazoval Helfert v 50. letech 19. století coby úředník ministerstva kultu a vyučování také v oblasti historického bádání a z něj vycházející literatury určené ke vzdělání širokých vrstev obyvatelstva. Helfert věřil, že „Velké Rakousko jest providenciálni nutností, netoliko v soustavě státni rovnováhy v Evropě, nejenom jakožto pưda prolnuti a smiřreni západni a východni evropské vzdělanosti, severnich a jižních mravů, románsko-germánského a řecko-slovanského živlu, nýbrž stejně tak v zájmu, ke zdaru a prospěchu každé z rozdilných

8 Ještě v Riegerově slovníku naučném (vyd. v Praze roku 1863) bylo Helfertovi vyčítáno propojení s konzervativními kruhy, z nichž na jaře 1849 vzešlo rozehnání kroměřížského sněmu, polemika s Palackým a podíl na zř́izení katolicky konzervativního Vídeňského deníku, který byl v opozici vůči Slovanu a Kutnohorským listům vydávanými K. H. Borovským, a za ospravedlňování germanizace ve školství)

9 ŠTAIF, Jiří. Historici, dějiny a společnost. Historiografie v českých zemích od Palackého a jeho předchůdců po Gollovu školu, 1790-1900, část 1, Praha 1997, s. 148.

10 KUČERA, Rudolf, op. cit., s. 321. 
součástek, z nichž během dob srostlo v mocný organism celkovy““. ${ }^{11} \mathrm{~V}$ ovzduší vyhrocujících se nacionálních sporů a nespokojenosti českých liberálů s oficiální rakouskou politikou druhé poloviny 19. století se Helfertův postoj celorakouského vlastenectví a loajality k dynastii ukazoval být stále více nereálným a jako takový byl také pozdější českou historiografií odsouzen. V české historické produkci posledních deseti let však postoje Josefa Alexandra Helferta opět nacházejí porozumění a jeho úloha v dějinách české státnosti a rakouské politiky se zdá být opět doceněna. ${ }^{12}$

\section{Josef Alexander Helfert jako historik a publicista}

Oblastmi, v nichž po sobě Josef Alexander Helfert zanechal nejrozsáhlejší dílo a které se u něj často navzájem propojovaly, jsou historiografie a publicistika. Co do počtu prací i co do rozmanitosti zpracovávaných témat je toto dílo velmi rozsáhlé a není v možnostech této studie jej přehlédnout v celé jeho šíri.

Josef Alexander Helfert nebyl a ve své době ani nemohl být školeným historikem univerzitního typu (nebyl jím ostatně ani František Palacký). Byl právníkem a politicky činnou osobou ve službách rakouského establishmentu, což se pochopitelně výrazně promítalo do volby jím zpracovávaných témat. Navíc v souladu se svým výše popsaným politickým přesvědčením nenahlížel na tato témata $\mathrm{z}$ hlediska národně-politického nýbrž z pohledu nadnárodního, celorakouského: „národní dějiny“ pro něj „nejsou dějinami nějaké rasově význačné skupiny z mnohojazyčných a pestrých kmenů lidstva, nýbrž dějinami obyvatelstva náležejícího k sobě územně i politicky, obemknutého svazkem téže autority a spojeného pod ochranou téhož zákona““. ${ }^{13} \mathrm{Z}$ této Helfertem preferované „velkorakouské“ myšlenky (der großösterreichische Staatsgedanke) vycházela jeho prezentace rakouských dějin, jejíž platformou se měl stát roku 1854 založený Ústav pro rakouský dějezpyt. Roku 1865 inicioval Helfert vydání sedmnáctisvazkových rakouských dějin s názvem Österreichische Geschichte für das Volk. Sám do tohoto velkorysého projektu autorsky přispěl roku 1867 vytvořením posledního, sedmnáctého svazku pojednávajícího o dějinách napoleonských válek.

11 „[...] Groß-Österreich eine providentielle Nothwendigkeit ist, nicht allein im System des staatlichen Gleichgewichtes von Europa, nicht allein als der Verknüpfungs- und Versöhnungsboden west- und osteuropäischen Bildung, nord- und südländischer Sitte, des romano-germanischen und des gräko-slawischen Elementes, sondern eben so sehr im Interesse, zum Heile und Gedeihen jedes einzelnen der verschiedenen Bestandtheile, aus denen es im Laufe der Zeiten zu einem mächtigen Gesammtorganismus zusammenwuchs." Srov. HELFERT, Josef Alexander. Über Nationalgeschichte und den gegenwärtigen Stand ihrer Pflege in Oesterreich, Prag 1853, s. 53, český překlad cit. podle WERSTADT, Jaroslav. Politické dějepisectví devatenáctého století a jeho čeští představitelé (Kapitola z ideového vývoje moderní české historiografie). In Český časopis historický [dále jen $\check{C} \check{C} H$ ] XXVI (1920), sešit I-4, Praha 1921, s. 47.

12 Tuto tendenci vykazují práce zde již citovaného Rudolfa Kučery, který Helfertově politické kariéře v 50. letech 19. století věnoval roku 2004 svou diplomovou práci.

13 „[... [ Nationalgeschichte ist uns daher nicht die Geschichte irgend einer racenmäßig ausgezeichneten Gruppe aus den vielzüngigen und vielfarbigen Stämmen des Menschengeschlechtes, sondern die Geschichte einer territorial und politisch zusammengehörenden, von dem Bande der gleichen Autorität umschlungenen, unter dem Schutze des gleichen Gesetzes verbundenen Bevölkerung. Srov. HELFERT, Josef Alexander. Über Nationalgeschichte, s. 1-2, český překlad cit. podle WERSTADT, Jaroslav, op. cit., s. 46. 
Po založení samostatného Československého státu se Helfertvo pojetí rakouských dějin dočkalo z pochopitelných důvodů ostré kritiky. V roce 1920 napsal český historik Jaroslav Werstadt: „Výrazu národni uživá [Helfert] ve smyslu politickém, nikoli etnografickém a nepochopuje významu a síly moderni ideje národní, stojici proti fikci politické ,národnosti rakouské“". 14

Hlavním předmětem Helfertova historického bádání se staly revoluční události let 1848 a 1849, která prožil coby mladý, sotva třicetiletý poslanec říšského sněmu a posléze vládní úředník. Pomineme-li díla menšího rozsahu, zanechal po sobě Helfert dvě rozsáhlé práce pojednávající o tehdy soudobých dějinách: čtyřdílné Geschichte Österreichs vom Ausgang des Wiener Oktoberaufstandes 1848 (1869-1886) a dvoudílné Geschichte der österreichischen Revolution im Zusammenhange mit der mitteleuropäischen Bewegung in den J. 1848-1849 (1907-1909). Jak vidno, vracel se Helfert k tomuto tématu až do konce svého života. Díky stále většímu časovému odstupu od oněch událostí, s narůstající životní zkušeností i s přibývajícími dostupnými prameny měl patrně potřebu nahlížet na ně vždy novým pohledem. Další okruh jeho dlouhodobého zájmu tvořily dějiny rakouského soustátí a Itálie v době napoleonských válek, o kterých pojednávají především díla Kaiser Franz und die Befreiungskriege (1867), Königin Karoline von Neapel im Kampfe gegen französische Weltherrschaft 1790-1814 (1878) a Kaiser Franz und die Stiftung der Lombardisch-Venezianischen Königreichs (1901). Věnoval se však i starším obdobím rakouských i českých dějin.

Po Helfertově smrti roku 1910 uveřejnil přední český historik a představitel univerzitní vědy Jaroslav Goll, který se s Josefem Alexandrem znal coby člen panské sněmovny, nekrolog v Českém časopise historickém. Konstatoval, že „dílo Helfertovo není historické dílo velkého slohu, ale cena jeho spočívá v látce a v pramenech, které se jemu otevřely snadněji, než komukoli po něm“. ${ }^{15}$

S odstupem téměř jednoho století vystihli pozici Josefa Alexandra Helferta v dějinách české historiografie velmi trefně František Kutnar a Jaroslav Marek. Helfertovo zcela zvláštní postavení mezi českými historiky 19. století spočívá dle těchto autorů ve skutečnosti, že byl více rakouským než českým nebo německým historikem a měl také jiný národní a sociální původ než jiní historikové jeho doby - a v neposlední řadě též úřední postavení v rakouském státním aparátu. Charakteristický je však pro Helferta, a v tom dáváme oběma historikům za pravdu, „určitý příklon k české společnosti“. Z Helfertova díla zmiňují Kutnar s Markem ve své publikaci (dokonce dvakrát) ono svrchu již jmenované dílo Hus und Hieronymus (vyšlo 1852 německy a 1857 česky), kde Helfert polemizoval s Palackého pojetím Husa a husitství. ${ }^{16}$ Jiným Helfertovým dílem, které se dočkalo reflexe

14 WERSTADT, Jaroslav. Politické dějepisectví devatenáctého století a jeho čeští představitelé (Kapitola z ideového vývoje moderní české historiografie). In ČČH XXVI (1920), sešit I-4, Praha 1921, s. 46. Naopak rakouský historik Alphons Lhotsky považoval v 60. letech 20. století tento směr v rakouské historiografii za Helfertem správně rozpoznaný naléhavý požadavek tehdejší doby, srov. LHOTSKY, Alphons. Österreichische Historiographie, Wien 1962, s. 198.

15 G[OLL], J[aroslav]. [Zpráva o úmrtí J. A. Helferta]. In $\check{C} \check{C} H$ XVI (1910), s. 257.

16 KUTNAR, František - MAREK, Jaroslav. Přehledné dějiny českého a slovenského dějepisectvi. Od počátků národni kultury až do sklonku třicátých let 20. století. Praha 1997, s. 263-264 a 315-316. 
v české odborné literatuře (tentokrát v oboru religionistiky) je stat’ O tak řečených blouznivcích náboženských v Čechách a na Moravě za císaře Josefa II. ${ }^{17}$

Je též nutno zmínit publikaci Die österreichische Volksschule pocházející z doby Helfertova působení na ministerstvu kultu a vyučování, kdy spolu s ministrem Lvem hrabětem Thunem-Hohensteinem spolupracoval na reformě rakouského školství.

Vezmeme-li v úvahu tento široký záběr témat, kterými se Josef Alexander Helfert zaobíral, a nahlédneme-li přitom do spisu Vladimíra Helferta Moje literární plány ze 40. let 20. století, nemůžeme se ubránit myšlence na nápadnou podobnost vnuka s dědečkem.

\section{Činnost Josefa Alexandra Helferta v oblasti ochrany uměleckých památek a jeho vztah $k$ církvi}

Jak již bylo zmíněno, byl Josef Alexander Helfert roku 1863 jmenován prezidentem Ústřední komise pro zachování památek. Tato komise, pod níž fungoval tým konzervátorů, si za Helfertova působení během 2. poloviny 19. století vydobyla značnou odbornou reputaci. Jako doklad zmiňme dopis, v němž Helferta coby prezidenta této komise žádal v září roku 1905 hrabě Haugwitz o odborný posudek na cenný umělecký předmět (alte Monstranz gottischen Styl 's), který byl rodinnou památkou uloženou na hradě Bítově. ${ }^{18}$

Seznamy Helfertovy korespondence dokazují fakt, že byl ve styku s příslušníky katolického kléru, diecézního i řeholního. Josef Alexander Helfert byl stejně jako jeho otec odborníkem na kanonické právo a coby prezident komise pro zachování památek měl zajisté co dočinění s duchovenstvem na rovině čistě úřední. Zároveň se však po celý svůj život, a zvláště v jeho závěrečném období na přelomu 19. a 20. století, zapojoval coby aktivní laik do života církve. Spolu s podobně smýšlejícím knězem, profesorem vídeňské univerzity a též rodákem z Čech, P. Franzem Martinem Schindlerem, založil roku 1892 společnost Leo-Gesellschaft pojmenovanou po tehdejším papeži Lvu XIII., která měla za úkol šírit katolickou vědu a kulturu. Mnoha kněžím byl proto Helfert důvěrně známou osobou a s mnohými se přátelil, jak napovídá tón některých dopisů, přestože v nich stále zůstává ono oficiálně zdvořilé oslovení Euer Excellenz. ${ }^{19}$ Můžeme se proto domnívat, že právě ona neformálnost ve styku s některými kněžími a řeholníky a zároveň úcta a vážnost, jimž se Helfert v církevních kruzích těšil, zajistila později jeho vnukům cenný sociální kapitál. Jako nositelé př́ijmení Helfert spojeného s vysokým morálním kreditem měli Vladimír a Jaroslav v době kolem roku 1920 bezesporu usnadněnou komunikaci s církevními kruhy a následkem toho i snadnější cestu k podchycování nejcennějších historických památek v majetku církevních institucí.

17 Tato Helfertova stat vyšla na pokračování v Časopise musea království Českého v letech 1877 a 1879 . Jako jeden ze svých informačních zdrojů ji průběžně cituje religionista Zdeněk R. NEŠPOR ve studii Vnější označení a sebeoznačení českých nekatolíků v 18. a 19. století. In Religio, 10 (2002), č. 2, s. 215-236.

18 MZA Brno, fond G 44, kart. 29, inv. č. 1210.

19 Srov. např. dopisy rajhradského benediktina a archiváře P. Maura Kintera, kterému Josef Alexander Helfert poslal svoji fotografii s věnováním, MZA Brno, fond G 44, kart. 35, inv. č. 1689. 


\section{Josef Alexander Helfert a česká lidová poezie - korespondence s Otakarem Hostinským}

Dochovaná korespondence obou mužů, přesněji řečeno dopisy Hostinského Helfertovi z let 1891-1894, ${ }^{20}$ dokládají nejen Helfertův přímý kontakt s budoucím učitelem jeho vnuka Vladimíra, ale poukazují na Helfertův zájem o podchycení významné části nehmotného kulturního dědictví českého národa - lidové poezie. Iniciátorem vzájemné komunikace byl v červenci roku 1891 Otakar Hostinský. Jsa tehdy spolupracovníkem na připravované publikaci Die Österreichisch-Ungarische monarchie in Wort und Bild, oslovil Helferta česky psaným dopisem jakožto budoucího autora stati o českých „prostonárodních písních“. Sám Hostinský měl do svazku věnovaného Čechám přispět kapitolou podobného obsahu (Musik und Volksmusik) a potřeboval si ujasnit, o čem konkrétně bude psát on a o čem Helfert: „soudím z toho“, píše Hostinský, „že úloha jest rozdèlena asi tím způsobem, že Vaše Excellencí [sic] ráči pojednati hlavně o textech písni těch, kdežto mně ponechána je předevšim stránka hudebni. Vím, že oboje nedá se naprosto od sebe odděliti, ale co mne se týká, mohu zcela dobře přihližeti $k$ nápěvuim v proní řadé, a slov dotýkati se jen tou nevelkou měrou, kterou můj úkol hudebni nezbytně by vyjadřoval, a tak hodlám i učiniti. Od rozbíráni a oceňováni básnické povahy a kulturního významu textů upouštím velmi rád, a to tím spiše, ano oceněni to vymezeno jest na spisovatele stati ,Volkslied und Tanz'v knize ,Die Čechoslaven“."

V dalších dopisech zodpovídá Hostinský Helfertovy dotazy týkající se konkrétních okruhů české lidové poezie a tanců, posílá Helfertovi své texty i odkazy na příslušnou literaturu. V souvislosti s touto korespondencí lze také blíže datovat či alespoň časově umístit množství Helfertových více či méně uspořádaných a mnohdy letmo psaných poznámek na volných listech, které obsahují citace českých lidových písní a říkadel (i s př́islušnými odkazy na Erbenovu sbírku) a k tomu též německé překlady Helfertovi neznámých českých výrazů převzatých z těchto ř́kadel. ${ }^{21}$ Zájem Josefa Alexandra Helferta o českou lidovou poezii se později zúročil v zájmu jeho vnuka Vladimíra o výzkum moravských lidových písní.

\section{Mozart a Pražané - Josef Alexander Helfert hostem na poli hudební historiografie}

Josef Alexander Helfert zasáhl svým dílem částečně i do oblasti hudebněhistorické, i když nikoli v pozici odborníka, ale poučeného laika. Zatím jediným důkazem jeho hostování v oboru vlastním později jeho vnukovi Vladimírovi je text Mozart und die Prager zachovaný ve strojopisné podobě. Strojopis o osmi stranách s vepsanými rukopisnými korekturami autora, dle kterých jej lze datovat do doby po roce 1879, se dochoval v archivu Moravské galerie v Brně ve fondu rodiny Helfertovy. ${ }^{22}$ Jedná se o popularizační článek určený

20 MZA Brno, fond G 44, kart. 32, inv. č. 1428.

21 Archiv MG v Brně, fond Rodina Helfertova, kart.1, nefol.

22 Archiv MG v Brně, fond Rodina Helfertova, kart. 1, nefol. Rok 1879 jsme určili za datum post quem vzhledem k jedné z rukopisných poznámek autora odkazujících na tento rok. 
patrně k publikování v denním tisku pro širokou veřejnost. Sám Josef Alexander hned v úvodu textu doznává, že co se týče informací o Mozartových pražských pobytech, nepřináší jeho text nic nového a přebírá všechny informace ze 4. svazku Mozartova životopisu od Otto von Jahna. ${ }^{23}$ První vydání tohoto čtyřsvazkového díla, z něhož Josef Alexander Helfert čerpal, a které vyšlo ke stému výročí skladatelova narození v letech 1856-59, se dodnes dochovalo v knihovně Vladimíra Helferta v Oddělení dějin hudby MZM v Brně. Josef Alexander Helfert neopomněl již v úvodu zdůraznit náklonnost a vřelý vztah Pražanů k Mozartovi, silně kontrastující s nezájmem Vídeňanů, a též zásluhu obyvatel Prahy na ocenění Mozartova díla již za jeho života. V dalším textu shrnul Helfert informace týkající se pražských provedení oper Únos ze Serailu, Figarova svatba, Don Giovanni a La Clemenza di Tito. K výpiskům z Jahnova díla přidal Helfert citát z Wiener Zeitung z 24. prosince 1791, kde je popsána zádušní mše za Mozarta sloužená dne 14. prosince 1791 v chrámu sv. Mikuláše v Praze na Malé straně. I zde Helfert vyzdvihl úctu Pražanů k Mozartovi, v níž hlavní město českého království předčilo i po skladatelově smrti rakouskou metropoli Vídeň. Na konec svého textu potom Helfert umístil vzpomínku na pražského harfenistu, kterému kdysi sám Mozart při jednom ze svých pobytů v Praze zkomponoval píseň. Tento harfenista byl ještě ve 30. letech 19. století v Praze známou osobou, které se pro její tehdy již staromódní oblek a rokokový účes žertem přezdívalo „Copánek“. Díky své osobní zkušenosti s Mozartem se však onen harfenista těšil všeobecné úctě. ${ }^{24}$ Sám Josef Alexander Helfert, narozený roku 1820 v samém centru Prahy, musel v mládí tohoto harfenistu znát. Konec jeho textu proto vyznívá jako hold tomuto poslednímu pamětníkovi na pražské pobyty velkého skladatele a zároveň jako vyznání pražského patriota, hrdého na mozartovskou tradici svého rodného města.

\section{Josef Alexander Helfert a jeho vnuci}

Jediný syn Josefa Alexandera Helferta a jeho první ženy Vilemíny Zdeněk (Josef Vilém Zdenko) Helfert narozený roku 1849 v Praze, se roku 1877 oženil s Marií Marešovou, s níž měl šest dětí: Zdeňka, Jaroslava, Marii, Vladimíra, Ludmilu a Miladu. Až do Zdeňkovy smrti v roce 1891 žila rodina v jihočeské Bechyni. Poté se vdova Marie Helfertová přestěhovala s dětmi do Prahy. Písemné doklady o kontaktu vnoučat s dědečkem Josefem Alexandrem žijícím ve Vídni se datují od roku 1890. Jménem sourozenců Helfertových posílal dědečkovi přání k svátku a narozeninám nejprve Jaroslav. Roku 1890 mu napsal k 70. narozeninám: „Náš drahý dědečku! Ku Toým milým narozeninám chci Ti já za sebe i za mé mladši sestřičky i bratřička práti: Abys dlouho ještě živ byl; nikdy abys nestonal a nás hodně rád měl. Posýláme [sic!] Ti každý k Tuým narozeninám mnoho hubiček a přijed’ k nám brzy. Tvi̊j vnouček Jara." Pozdější dochovaná přání psal Jaroslav svému Großpapa již německy

23 Helfert použil první vydání, které vyšlo ke stému výročí Mozartova úmrtí v letech 1856-1859 v Lipsku, a cituje dle svých slov pouze z kapitol pojednávajících o Mozartových pražských pobytech, tj. ze 4. dílu od s. 278 dál.

24 K pražskému setkání Mozarta s harfenistou Haüsslerem přezdívaným Copánek srov. NETTL, Pavel. Mozart v Čechách, Praha 1939, s. 78-83. 
a úhledným žákovským kurentem. Na společná přání se již podpisovali také Vladimír, Marie, Ludmila a Milada. Roku 1896 napsal dědečkovi k svátku z Prahy i desetiletý Vladimír: „Guter Großpapa! Ich wünsche dir zum Namenstage daß du lange lebest. Komme zu uns bald und bleibe gesund. Dein dankbahrer Enkel Vláda." O rok později, v březnu 1897, napsal Vladimír z Prahy o chystané návštěvě divadla, na kterou se oba s Jaroslavem velmi těší: „Lieber Großpapa! Nimm mein innigsten Glückwünsche! Der liebe Gott erhalte dich noch viele Jahre gesund! Was machst du immer lieber Großpapa! Hier ist jetzt eine Theatergesellschaft und die Mama versprach uns, mich und Jara einmal in Theater zu erlauben, worauf wir uns sehr freuen. Vielmals küst dir und die Großmama die hand dein dankbarer Enkel Vláda." ${ }^{25}$

Ačkoliv byli vnuci Josefa Alexandra již vychováni česky, komunikovali se svým dědem až do jeho smrti v německém jazyce. Josef Alexander měl přímý vliv na jejich vzdělávání a odborné směřování. Důkazem toho je německy psaný dopis historika a univerzitního profesora Jaroslava Golla z roku 1904. Tento pozdější učitel Vladimíra Helferta na Karlově univerzitě se u Josefa Alexandra Helferta přimlouvá za jeho staršího vnuka, tehdy již devatenáctiletého studenta Jaroslava Helferta. Dle Gollova názoru by Jaroslavovi kvůli jeho ne př́liš pevnému zdraví svědčilo stát se spíš knihovníkem a archivářem nežli gymnaziálním profesorem. Snad můžeme za nepřímý důsledek této Gollovy intervence považovat i fakt, že se Jaroslav již pět let poté, roku 1909, stal sekretářem a roku 1923 ředitelem Moravského zemského muzea v Brně. ${ }^{26}$

Jistě se v budoucnu objeví další prameny dokumentující vztah Josefa Alexandra k jeho vnukům a poskytnou ucelenější obraz rodinného prostředí, v němž Jaroslav a Vladimír Helfertové vyrůstali.

Zde předložený stručný výběr z tvorby a aktivit Josefa Alexandra Helferta již z velké části naznačil, v čem tento nesmírně aktivní a činorodý muž mohl být a také byl svým vnukům vzorem.

V př́ípadě Jaroslava Helferta se jeví být celkem jasná návaznost na snahu Josefa Alexandra o záchranu uměleckých památek.

U Vladimíra, o kterém bylo dosud napsáno nesrovnatelně více literatury než o jeho starším bratrovi, je srovnávání s jeho dědem poněkud obtižnější. Studie zabývající se vztahem Josefa Alexandra a Vladimíra Helfertových ${ }^{27}$ mají tendenci zdůrazňovat v intencích nacionalisticky laděného dějepisectví 20 . století spíše protiklady obou osobností: na jedné straně Josef Alexander - Rakušan (či dle Roberta Smetany dokonce rakouský Němec), konzervativec, monarchista, klerikál, politik a k tomu šlechtic, na straně druhé Vladimír - Čech, demokrat, který se vzdal šlechtického titulu, pokrokový levicový intelektuál spolupracující za 1. světové války s Maffií a univerzitní vědec nezasahující do reálné politiky. Pokud však odhlédneme od tohoto hodnocení obou osobností vytvořeného podle šablony dosavadního oficiálního pohledu na politické dějiny českého národa

25 Gratulace vnoučat adresované Josefu Alexandrovi jsou uloženy v MZA, fond G 44, kart. 31, inv. č. 1296, fol. $17 \mathrm{r}$ a $35 \mathrm{rv}$.

26 Dopis uložen v MZA, fond G 44, kart. 27, inv. č. 1024.

27 Eva DRLÍKOVÁ, op. cit. a SMETANA, Robert: Vladimír Helfert a Brno, in: Opus musicum XVII (1985), č. 5 , s. 131-135. 
v 19. a 20. století, najdeme jeden společný rys, který je pro jejich hodnocení zásadnější než všechny výše jmenované rozdíly.

Josef Alexander byl politikem činným ve vládních strukturách. Vladimír oficiálně politikem nebyl, ačkoli přiznal, že se cítí být tímto světem přitahován, byt̉ mu byla milejší věda: „A pro to všse mám svou vědu rád. A proto také se bráním vstoupit do okruhu politických zájmů, ač se přiznávám, že mě politika často živelně pritahuje a že můj zájem o politiku je často palčivě naléhavý. Vždyt politika - to je také život a práce politická je, nebo alespoñ má být, rovněž ona synthesa umělecké a kritické tvorby. Ale vím, kdybych se dal do politiky, že by to nutně znamenalo, že opouštím svou vědu. A této zrady na své vèdě se chci vystř́h ${ }^{\prime \prime}{ }^{28}$ Fakticky ale Vladimír Helfert „politikem“ svého druhu byl, byt vytvářel politiku jinými prostředky než Josef Alexander. Jeho spis Naše hudba a český stát z roku 1918 i jeho korespondence z doby přípravy, zrodu a následného budování samostatného Československého státu (např. s Otakarem Jeremiášem, Zdeňkem Nejedlým, Ludvíkem Čelanským aj.), dokládá, že hudební a obecně kulturní dění, v němž se Vladimír Helfert aktivně angažoval, bylo $\mathrm{v}$ té době vysoce politickou záležitostí. Rozhodně nebyl sám, kdo se takto angažoval připomeňme zde např. Manifest českých spisovatelů požadujících založení samostatného státu z května roku 1917. Propojení kultury, umění a také dějepisectví s reálnou politikou bylo v této přelomové době minimálně stejně důležité jako v revolučních letech 1848-49 a době bezprostředně následující, kdy do politiky i historiografie stejně tak aktivně zasahoval mladý a agilní právník Josef Alexander Helfert. Oním společným rysem děda a vnuka je tedy skutečnost, že oba dva měli ve chvilích pro české dějiny rozhodujících potřebu konat a nikoli pouze nečinně přihlížet (tento postoj se také Vladimíru Helfertovi stal za 2. světové války osudným). Fakt, že jeden z nich tak činil z pozic konzervativně smýšlejícího, loajálního rakouského občana a druhý z pozice pokrokového liberála, zde není až tak důležitý. Patřičné ocenění si rozhodně zaslouží oba dva.

Závěrem zbývá pouze zopakovat, co již bylo svrchu napsáno, totiž že k poznání a patř̌ičnému docenění osobnosti Josefa Alexandra Helferta a jeho vlivu na odborné směřování Jaroslava a Vladimírova Helfertových je třeba hlubšího a dlouhodobějš́ího pramenného výzkumu.

Tato studie vznikla za finanční podpory Ministerstva kultury v rámci institucionálního financováni na dlouhodobý koncepčni vývoj výzkumné organizace Moravské zemské muzeum (DKRVO, MK000094862).

28 Srov. STRAKOVÁ, Theodora. Vladimír Helfert 24.III.1886-18.V. 1945. K výstavě „Vladimír Helfert a jeho tvưrči odkaz", Brno 1956, s. 13. 


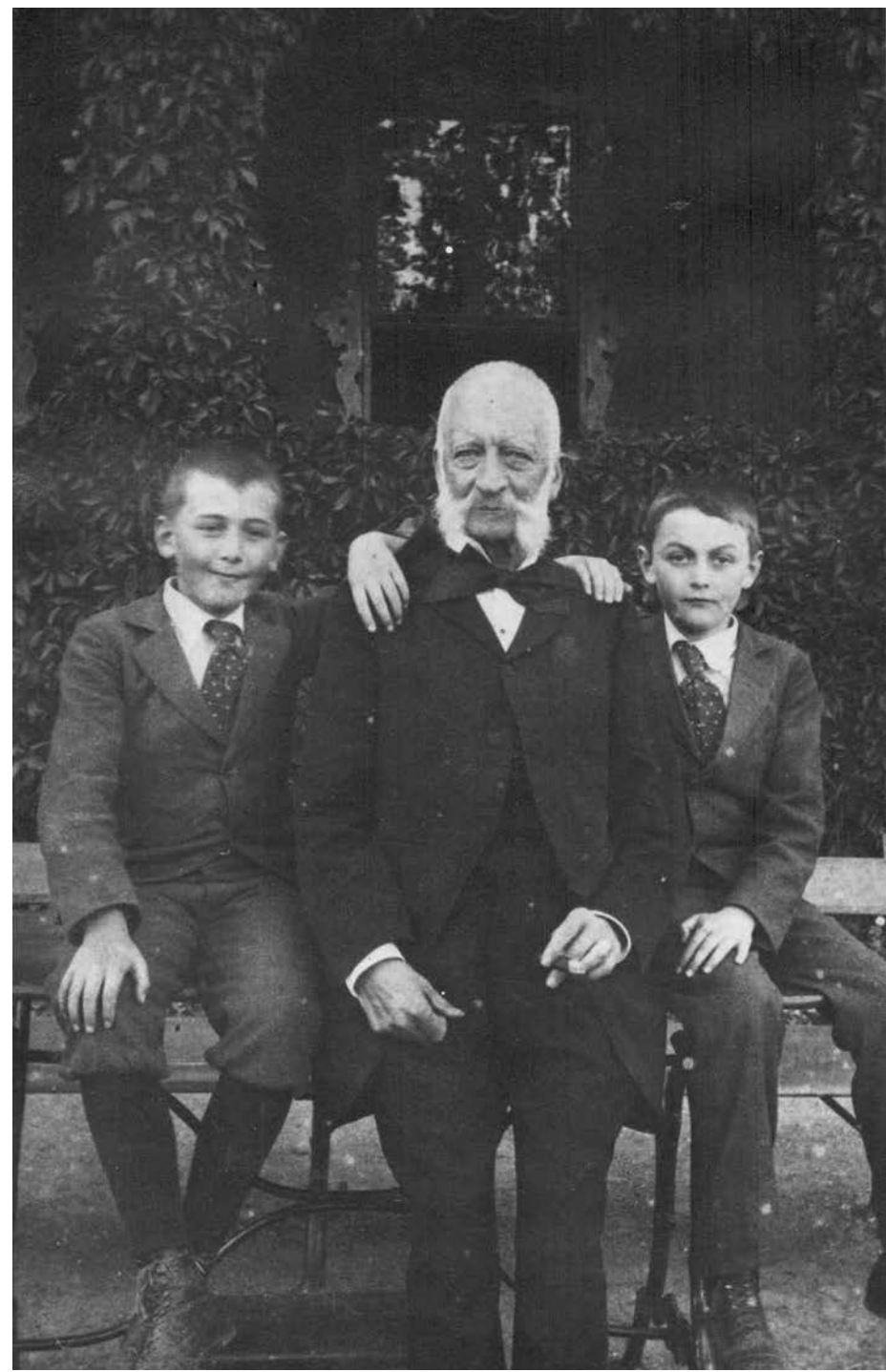

Obr. 1. Josef Alexander Helfert s vnuky Jaroslavem a Vladimírem v Klosterneuburgu, 1898, ODH MZM, sign. F 1212. 


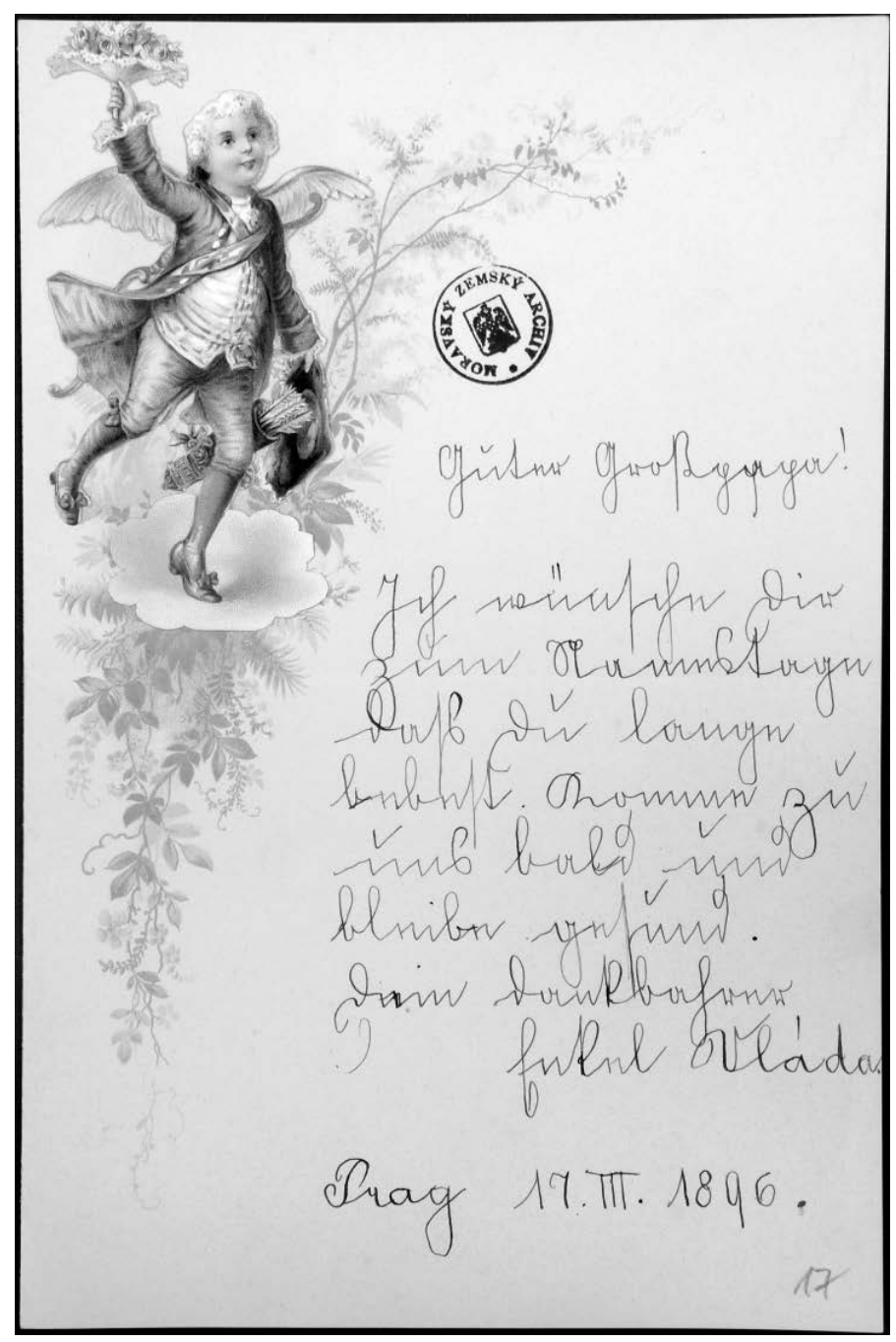

Obr. 2. Prání desetiletého Vladimíra Helferta Josefu Alexandrovi k svátku, 1896, MZA, fond G 44, kart. 27, inv. č. 1024. 


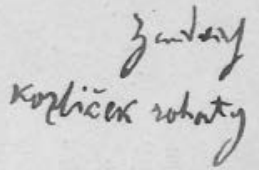

$$
\begin{aligned}
& \text { na tor nasisn Oràe } \\
& \text { viteses to kriapile }
\end{aligned}
$$

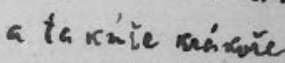

$$
\begin{aligned}
& \text { holi po June }
\end{aligned}
$$

a ten vit jake kid

a th kiáva onhixo dava' III use iss.

a to tele holubon nde

$$
\text { obrox fith filloni }
$$

Kotyotartinstí
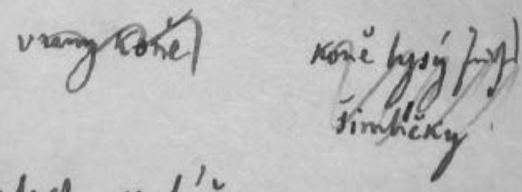

$$
\begin{aligned}
& \text { mad mé ra cesté valuch vall'́jer }
\end{aligned}
$$

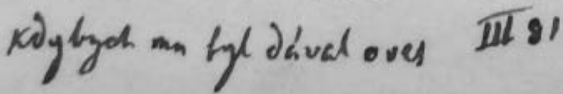

$$
\begin{aligned}
& \text { mot jisan mit polnes }
\end{aligned}
$$

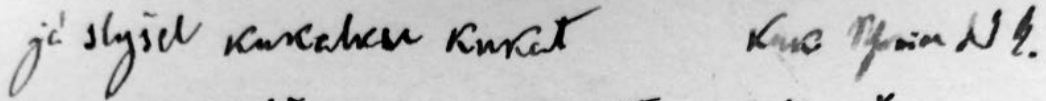

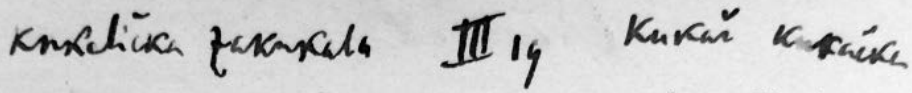 má parnemses fepplaxila Kon $\times$ ali

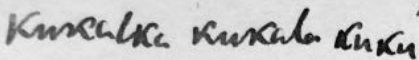

Obr. 3 a 4. Vlastnoruční zápisy Josefa Alexandra Helferta z české lidové poezie, 90. léta 19. stol., Archiv MG, fond Rodina Helfertova, kart. 1, nefol. 


\section{Bibliography}

ČERNUŠÁK, Tomáš. G 44 - Helfertovi (1812-1910). Inventář MZA v Brně. Brno 2014.

DRLÍKOVÁ, Eva. Vladimír Helfert a jeho rod (Od barona k občanovi). In Vladimír Helfert v českém a evropském kontextu. Hudebněvědná konference $k$ 100. výroči narozeni pokrokového vědce a člověka. Brno 1987, s. 102-105.

G[OLL], J[aroslav]. [Zpráva o úmrtí J. A. Helferta]. In ČČH XVI (1910), s. 257.

HELFERT, Josef Alexander. Über Nationalgeschichte und den gegenwärtigen Stand ihrer Pflege in Oesterreich. Prag 1853.

HELFERT, Vladimír - SOSNAR, Jura. Hovory tužkou: Listy spoluvězněnému přiteli, Moje literárni plány (1941-42) (= Knižnice hudebních rozhledů), Praha 1956.

KOŘALKA, Jiří. František Palacký (1798-1876). Životopis. Praha 1998.

KUČERA, Rudolf. Konzervativní poučení z revoluce. Politická kariéra J. A. Helferta. In Moderni dějiny 14 (2006), s. 309-321.

KUTNAR, František - MAREK, Jaroslav. Přehledné dějiny českého a slovenského dějepisectví. Od počátků národni kultury až do sklonku třicátých let 20. století. Praha 1997.

LHOTSKY, Alphons. Österreichische Historiographie. Wien 1962.

NEŠPOR, Zdeněk R. Vnější označení a sebeoznačení českých nekatolíků v 18. a 19. století. In Religio, 10 (2002), č. 2, s. 215-236.

NETTL, Pavel. Mozart v Čechách. Praha 1939.

NODL, Martin. Národní a zemské zájmy v interpretacích „dekretu kutnohorského“ (Palacký Tomek - Helfert - Höfler). In AMBROŽOVÁ, Hana - DVOŘÁK, Tomáš - CHOCHOLÁČ, Bronislav - JAN, Libor - PUMPR, Pavel (eds.). Historik na Moravě. Profesoru Jiř́mu Malírovi, predsedovi Matice moravské a vedoucímu Historického ústavu FF MU, věnuji jeho kolegové, přátelé $a$ žáci $k$ šedesátinám. Brno 2009, s. 77-90.

NODL, Martin. Dějepisectvi mezi vědou a politikou. Úvahy o historiografii 19. a 20. století (= Dějiny a kultura, sv. 14), Brno 2007.

PEČMAN, Rudolf. Vladimír Helfert. Brno 2003.

SMETANA, Robert. Vladimír Helfert a Brno. In Opus musicum, XVII (1985), č. 5, s. 131-135.

STRAKOVÁ, Theodora. Vladimír Helfert 24. III. 1886 - 18. V. 1945. K výstavě „Vladimír Helfert a jeho tviorrč odkaz“. Vyd. Moravské museum, Brno 1956.

ŠTAIF, Jiří. Historici, dějiny a společnost. Historiografie v českých zemich od Palackého a jeho predchůdců po Gollovu školu, 1790-1900, část 1. Praha 1997.

URBAN, Otto. Česká společnost 1848-1918. Praha 1982.

WERSTADT, Jaroslav. Politické dějepisectvi devatenáctého století a jeho čšsti prèdstavitelé (Kapitola z ideového vývoje moderni české historiografie). In ČC̆H XXVI (1920), sešit I-4, Praha 1921, s. 1-93. 